\title{
UK embryo agency faces the axe
}

\section{Coalition government promises to abolish respected regulator in effort to cut back on quangos.}

In the ethically fraught field of human-embryo research, Britain's Human Fertilisation and Embryology Authority (HFEA) has long been regarded as a world leader in regulating and advising scientists.

But now the HFEA faces the axe, and researchers and politicians are chorusing their discontent. "I'm absolutely astonished at this," says Ruth Deech, an independent member of the House of Lords and former chair of the HFEA. "I think our standing in the world will be reduced."

Since it was created by the Human Fertilisation and Embryology Act in 1990, the HFEA has regulated fertility treatment and research involving human embryos in the United Kingdom (see 'The development of an embryo agency'). Its work involves inspecting and licensing centres, as well as providing ethical and legal advice to scientists and the public. Scientists have generally applauded the HFEA for providing a clear set of boundaries for what research is permissible. "It's looked upon as an organization that is often the first to make decisions that define scientific and clinical barriers," says Justin St. John, director of the Centre for Reproduction and Development at the Monash Institute of Medical Research in Melbourne, Australia. Countries such as Australia and Canada have established similar agencies using the HFEA as a model. "It is the envy of American researchers and biotech companies," adds Paul Wolpe, director of the Emory Centre for Ethics in Atlanta, Georgia.

The HFEA is threatened because Britain's new coalition government has pledged itself to a "radical simplification" of the regulatory landscape for public health and medical research. Health secretary Andrew Lansley announced last week that the number of health agencies will be reduced from 18 to "between eight and ten", to reduce overlap between the bodies and save $£ 180$ million (US $\$ 285$ million). The move is part of a bigger push to make public spending cuts by closing 'quangos' - quasi-autonomous non-governmental organizations - many of which perform regulatory functions on behalf of the government.

The government says that the HFEA's regulatation of fertility treatments will move to the Care Quality Commission, one of the health quangos to survive the cull. But its research licensing work will probably move to a new super-regulator that would also absorb the functions of the Human Tissue Authority (HTA), which oversees organ donation and the use of human tissues in research and teaching. The government says the HFEA and the HTA will be abolished by April 2013.

"I think amalgamation would be a loss," says St. John, who held an HFEA licence for research using 'cybrid' embryos - created by putting human DNA into an empty animal egg - when he worked at the University of Warwick, UK. "You might lose expertise and considerable knowledge."

If the clinical and research aspects of embryology were divided, "it would risk spreading the available expert advice thinly across two bodies", says Martin Bobrow, emeritus professor of medical genetics at the University of Cambridge, UK.

After Britain's previous government mooted similar reforms in 2004, research charities and academics queued up to decry plans to merge the HFEA, the HTA and parts of the Medicines and Healthcare Products Regulatory Agency into a new Regulatory Authority for Tissue and Embryos. Some said the bodies' functions were too different for a merger to work; others feared the loss of specialist expertise that might result. The plans were abandoned after a cross-party parliamentary inquiry held in 2007 concluded that the case against a merger was "overwhelming and convincing". The inquiry heard evidence that the HFEA's remit was fundamentally different from, and more ethically complex than, the HTA's. Many of those consulted warned that losing the HFEA as a discrete body could undermine public confidence in the regulations it enforced; and that even as part of a larger organization, it would still need the same resources to operate effectively, limiting any cost savings. Deech, who was on that inquiry committee, says that the merger plan "was comprehensively demolished three years ago for very good reasons, which are just as good today".

\section{Health hazard}

A more immediate casualty of the 'bonfire of the quangos' is likely to be the Health Protection Agency (HPA), which provides advice and guidance on infectious diseases and environmental hazards. The government says that the HPA's work will migrate into the Department of Health by April 2012. This has raised alarm bells with some scientists. "Will the new service be able to give advice that is in the best interests of public health, whether or not it conflicts with policy and interests of whatever government is in power?" asks Paul Hunter, a professor of health protection at the University of East Anglia in Norwich, UK. "The HPA currently does a lot of good research that ultimately benefits the public health," he adds. "Will this still continue in the new service, or if not, how will the gap be filled?" Further details on the reforms are expected after a wide-ranging review of medical-research regulation by the Academy of Medical Sciences, commissioned by the previous government, is completed this autumn.

Daniel Cressey

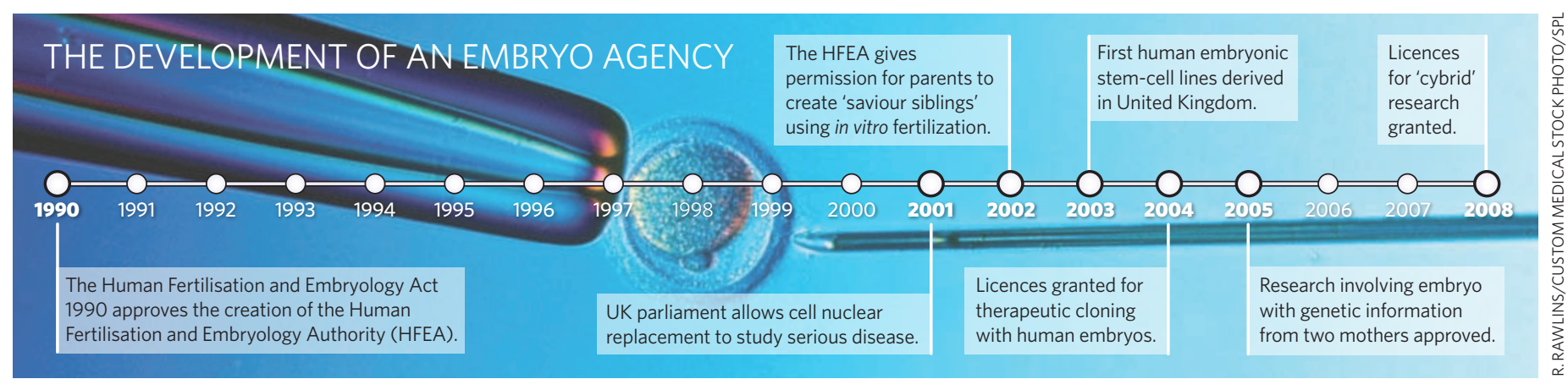

